\title{
Effects of Corbicula fluminea on the nutrient concentration and phytoplankton biomass of tropical reservoirs
}

\author{
Jessica Chappell 1 - Stefanie Whitmire - David Sotomayor-Ramírez • \\ Gustavo Martínez-Rodríguez
}

Received: 10 August 2019/Accepted: 9 November 2019/Published online: 16 November 2019

(C) The Author(s) 2019

\begin{abstract}
Invasive bivalves are known to negatively impact aquatic ecosystems across the globe. Previous research has demonstrated invasive bivalves can shift nutrients from the water column to the sediment, harm native bivalves, and reduce phytoplankton biomass. However, bivalve effects vary with species and the region where the invasion occurs. Therefore, we used mesocosm experiments to examine the impact of invasive Corbicula fluminea on nutrient concentration and phytoplankton biomass in the water column of mesotrophic and eutrophic Puerto Rican reservoirs. We used four treatments to determine the effect of $C$. fluminea on the water column. We found $C$. fluminea did not have a significant effect on the ammonium, nitrate, or phosphorus concentration in either the mesotrophic or eutrophic mesocosm experiments. Additionally, C. fluminea presence did not significantly alter phytoplankton biomass, though Synedra dominated the phytoplankton community when $C$. fluminea were absent. While $C$. fluminea may not have caused an effect in the water column as it was potentially phytoplankton limited, the mesocosm experiment conditions reflect the natural environment, indicating phytoplankton limitation could be an issue in the reservoirs. Our findings suggest $C$. fluminea does not have a large effect on nutrient concentration or phytoplankton biomass in eutrophic and mesotrophic Puerto Rican reservoirs. This study represents the first effort to examine the effects of $C$. fluminea presence on the water column of a tropical reservoir.
\end{abstract}

Keywords Corbicula fluminea $\cdot$ Phytoplankton $\cdot$ Nutrients $\cdot$ Reservoir $\cdot$ Tropics

\section{Introduction}

Invasive bivalves are an issue world-wide and can alter aquatic ecosystems via removal of organic matter from the water column, increasing the depth of light penetration and increasing nutrient availability (Strayer et al.

\footnotetext{
J. Chappell · S. Whitmire · D. Sotomayor-Ramírez · G. Martínez-Rodríguez

Agroenvironmental Sciences Department, College of Agricultural Sciences, University of Puerto Rico,

P.O Box 9000, Mayaguez, PR 00681, USA

Present Address:

J. Chappell ( $\square)$

Odum School of Ecology, University of Georgia, 140 E Green St, Athens, GA 30605, USA

e-mail: jchapp@uga.edu

Present Address:

S. Whitmire

Forestry and Environmental Conservation Department, Baruch Institute of Coastal Ecology and Forest Science, Clemson University, 101 Barre Hall, Clemson, SC 29634, USA
} 
1999; De Stasio et al. 2008). Additionally, bivalves can influence phytoplankton community structure through filter feeding (Strayer et al. 1999) and are able to shift the main energy pathway from pelagic to benthic based on nutrient concentrations (Vaughn and Hoellein 2018). Invasive bivalves can also negatively affect native bivalves by reducing their growth (Ferreira-Rodríguez et al. 2018). Though invasive bivalves have caused similar changes across ecosystems, their effects vary depending on characteristics such as bivalve traits and environmental nutrient loading (Vaughn and Hoellein 2018).

Corbicula fluminea (Müller 1774), a highly invasive clam, has had varying effects on water column nutrient concentrations. Some studies indicate $C$. fluminea could potentially decrease nutrient availability in shallow reservoirs, sequestering nutrients in the sediment by filtering the water column (Patrick et al. 2017). Meanwhile, other studies have found $C$. fluminea shift nutrients from the sediment to the water column (Coelho et al. 2018). Regardless of directionality, alterations in water column nutrient concentrations as a result of $C$. fluminea presence could affect the structure of the phytoplankton community.

Additionally, previous research has found $C$. fluminea can affect the phytoplankton community directly, reducing phytoplankton biomass through filter feeding (Cohen et al. 1984; Sousa et al. 2008). Though filter feeding removes phytoplankton from the water column, C. Aluminea can excrete partially digested phytoplankton cells, creating pseudofeces (Hill and Knight 1981; Vaughn and Hakenkamp 2001). Pseudofeces indicate the phytoplankton were not completely digested (Way et al. 1990). While it is unclear why some species may not be consumed, studies have suggested feeding preference may relate to phytoplankton size, nutritional content, or toxicity (Liu et al. 2009; Vaughn and Hoellein 2018).

C. fluminea have invaded aquatic ecosystems throughout the United States, South America, Europe, and Puerto Rico (Beasely et al. 2003; McMahon 2002; Williams et al. 2001). The first documented discovery of $C$. fluminea in Puerto Rico was in 1998 in the Cayey River on the north side of the island. Since its discovery, $C$. fluminea has been found in three different watersheds and its spread will likely continue throughout fresh and brackish waters across Puerto Rico (Williams et al. 2001). This study represents an important first step in understanding how to manage a potentially wide-spread invasive bivalve in Puerto Rico, as the effects of $C$. fluminea can vary by region (Rosa et al. 2011). Additionally, while one study has examined the effect of $C$. fluminea on the benthic community in neo-tropical reservoirs (Linares et al. 2017), this is the first to examine the impacts of $C$. fluminea on the phytoplankton community in tropical reservoirs.

In this study, we use mesocosms to determine the effect of $C$. fluminea on nutrient concentrations and phytoplankton community structure in two Puerto Rican reservoirs. Additionally, we examine whether the response magnitude of these two variables differed depending on feeding mechanism (i.e. only filter feeding or filter and pedal feeding). We also evaluate whether the initial nutrient concentration (eutrophic and mesotrophic) influences the impact of $C$. fluminea as other invasive bivalves seem to increase phytoplankton biomass more in low phosphorus environments, specifically cyanobacteria biomass (Raikow et al. 2004; Sarnelle et al. 2005; Knoll et al. 2008). Based on previous research, we hypothesized (1) treatments with $C$. fluminea will decrease phytoplankton biomass and nutrient concentrations in the water column more than treatments without $C$. fluminea present and (2) treatments with $C$. fluminea restricted to filter feeding will have less phytoplankton biomass and lower nutrient concentrations than treatments with $C$. fluminea that are able to filter and pedal feed.

\section{Materials and methods}

\section{Site description}

Puerto Rico has 18 major reservoirs spread throughout the island, and these reservoirs serve a variety of functions, including hydropower, drinking water, and recreation (DRNA 2008). We selected two reservoirs with differing trophic levels to examine whether the trophic classification of a reservoir influences the effect of C. fluminea on the ecosystem. We used water from Lago Guajataca and Lago La Plata as representative of reservoirs classified as mesotrophic and eutrophic, respectively. The mesotrophic Guajataca reservoir has a median total phosphorous (TP) concentration of $10 \mu \mathrm{g} / \mathrm{L}$ and a median total nitrogen (TN) concentration of $0.28 \mathrm{mg} / \mathrm{L}$ within $1 \mathrm{~m}$ of the surface, and the eutrophic La Plata reservoir has a median TP of $49 \mu \mathrm{g} / \mathrm{L}$ and median TN of $0.55 \mathrm{mg} / \mathrm{L}$ (Martínez-Rodríguez et al. 2015). 
Experimental design

We conducted two separate mesocosm experiments using water and sediment taken from a mesotrophic and eutrophic reservoir. We carried out the mesotrophic mesocosm experiment in March 2011, and the eutrophic mesocosm experiment in May 2011. We ran each mesocosm experiment for 14 days, which is within the running time frame of mesocosms evaluating nutrient effects by $C$. fluminea (6-18 days; Coelho et al. 2018; Crespo et al. 2018).

Each individual mesocosm was contained within a $20 \mathrm{~L}$ white plastic bucket $(30.5 \mathrm{~cm}$ diameter, $38.1 \mathrm{~cm}$ tall) and contained $11 \mathrm{~L}$ of reservoir water. The mesocosm treatments with sediment also contained $700 \mathrm{~g}$ ( $\sim 9 \mathrm{~cm}$ ) of reservoir sediment. Sediment was collected from the mesotrophic or eutrophic littoral zone of each reservoir and completely dried outside in ambient conditions prior to the start of the experiment. Although we did not formally analyze sediment features, the sediment used from both reservoirs was a mixture of fine silt and clay, likely originating from the surrounding land as these reservoirs experience high sediment loading (Ortíz-Zayas et al. 2004). We used the Olsen P method to determine the phosphorus content of both soil types (Pierzynski 2000) and found the mesotrophic sediment to have an Olsen P of $9.25 \mathrm{mg} \mathrm{P} / \mathrm{kg}$, while the eutrophic sediment had $20.25 \mathrm{mg} \mathrm{P} / \mathrm{kg}$. We collected the water from the littoral zone of the reservoirs using plastic buckets and transported the reservoir water to the experiment site on day 0 of the mesocosm experiment.

C. Aluminea individuals of the same size $(30.8 \mathrm{~mm} \pm 1.34 \mathrm{~mm})$ were collected from a pond located at the Agriculture Experimental Station in Lajas, Puerto Rico $\left(18^{\circ} 2^{\prime} 12^{\prime \prime} \mathrm{N}\right.$ and $67^{\circ} 3^{\prime} 55^{\prime \prime} \mathrm{W}$ ) and starved for $72 \mathrm{~h}$ prior to the experiment to avoid contamination via pseudofeces (Silverman et al. 1995). The clam treatments received ten clam individuals per bucket. This density was derived from the maximum density (172 individuals $/ \mathrm{m}^{2}$ ) observed in the literature (Karatayev et al. 2003) and scaling to the mesocosm size. We used the maximum observable clam density to evaluate the most extreme expected effects. Clam mortality was not significant, as only one individual died over the course of both experiments. The dead clam was removed and not replaced as only 1 day of the experiment remained. Additionally, there was no difference in clam biomass between the beginning and end of either experiment within individual mesocosms.

Each mesocosm was continuously aerated with a bubbler and experienced ambient air temperature shifts. While we placed the buckets underneath a shade cloth to minimize direct sun exposure, the mesocosms were subjected to natural light cycles $(\sim 12-13 \mathrm{~h}$ of sunlight). We measured irradiance during each experiment and recorded ranges between 685-944 $\mu \mathrm{mol} \mathrm{m}{ }^{2} / \mathrm{s}^{1}$ (March) and 1192-1368 $\mu \mathrm{mol} \mathrm{m}{ }^{2} / \mathrm{s}^{1}$ (May). Temperature, dissolved oxygen, and $\mathrm{pH}$ were measured in each mesocosm every other day using a YSI Pro Plus multiparameter handheld meter. We did not replace reservoir water within the mesocosms, which is consistent with other studies (Coelho et al. 2018; Crespo et al. 2018); however, treatments without sediment were manually stirred daily using a meter stick to maintain a homogenous mixture of the phytoplankton community. We did not stir sediment treatments to avoid sediment resuspension and to allow for chlorophyll $a$ and phytoplankton community sampling at the end of the experiment.

Both mesocosm experiments had 4 treatments and each treatment had 4 replicates, for a total of 16 mesocosms per experiment. One treatment had clams and reservoir water $(C+W)$, while a second treatment served as a control, with only reservoir water (W). These treatments isolated the impact of filter feeding on the pelagic phytoplankton community and nutrient concentrations. A third treatment included clams, reservoir water, and reservoir sediment $(\mathrm{C}+\mathrm{W}+\mathrm{S})$, and a fourth treatment had only reservoir water and reservoir sediment $(\mathrm{W}+\mathrm{S})$. With the inclusion of sediment, we could evaluate the potential additive effects of filter and pedal feeding on the phytoplankton community and nutrient concentrations in the water column. We assumed pedal feeding occurred in the sediment treatment $(\mathrm{C}+\mathrm{W}+\mathrm{S})$ since the clams were submerged, but we did not quantify pedal feeding.

We removed $420 \mathrm{~mL}$ of water to evaluate the phytoplankton community, chlorophyll $a$, and nutrient concentrations in all treatments on days $0,1,7$ and 14 . However, we were unable to determine the phytoplankton community structure and chlorophyll $a$ concentration on days 1 and 7 in sediment treatments due to the high amount of sediment in the samples. We took the day 0 sample before the experiment began (i.e. no sediment or $C$. fluminea present) to have an initial measurement for all water column parameters. To determine the concentration of nitrate $\left(\mathrm{NO}_{3}{ }^{-}\right)$and ammonium $\left(\mathrm{NH}_{4}{ }^{+}\right)$, we filtered the water sample using a $0.2 \mu \mathrm{m}$ glass microfiber filter (Whatman). We determined dissolved phosphate (DP) concentrations in the mesotrophic 
experiment, but total phosphate (TP) concentrations in the eutrophic experiment to obtain a better estimate of potentially available phosphorus as there was a large amount of suspended sediment in select treatments. The water samples were preserved with one drop of $\mathrm{H}_{2} \mathrm{SO}_{4}$ and sent to the Martinez-Rodriguez lab at the International Institute of Tropical Forest's Soil and Water Quality for processing where all analytical procedures were performed according to those established in an EPA-approved Quality Assurance Project Plan (QAPP) for nutrient levels in Puerto Rican reservoirs (USEPA 1999).

To examine the phytoplankton community, we preserved the sample using Lugol's solution and used a modified form of the Utermohl method (Utermohl 1958; Paxinos and Mitchell 2000) identifying phytoplankton to the lowest taxonomic level possible using several guides (Collins 1909; Smith 1950; Wehr and Sheath 2003). Through published geometric formulas, we calculated the average cell biovolume of each phytoplankton level (Hillebrand et al. 1999) and assumed phytoplankton had a specific gravity of $1 \mathrm{~g} / \mathrm{cm}^{3}$ to convert to wet biomass (Riemann et al. 1989; Knoll et al. 2008). We determined chlorophyll $a$ concentration using the protocol for identifying chlorophyll $a$ in marine and freshwater algae through fluorescence originated by the US Environmental Protection Agency (Arar and Collins 1997).

We used a repeated-measure ANOVA to compare phytoplankton biomass, chlorophyll $a$ concentration, and the physical parameters in SAS for each mesocosm experiment (version 9.1, (c) 2002-2003). We analyzed each reservoir separately, as our comparisons were focused on examining changes in all parameters both within and between treatments.

\section{Results}

Abiotic changes

The temperature in the mesotrophic experiment ranged from 18.7 to $29.2{ }^{\circ} \mathrm{C}$, while temperatures in the eutrophic mesocosms ranged from 23.9 to $32.2^{\circ} \mathrm{C}$. There was no significant difference between temperature, $\mathrm{pH}$, or dissolved oxygen among the four treatments in either study (Table 1) or between experiment days 1 and 14. In sediment treatments, chlorophyll $a$ and the phytoplankton community were only examined on day 14 , once the sediment settled out of the water column.

Mesotrophic experiment

Chlorophyll $a$ was lower in the $\mathrm{C}+\mathrm{W}$ treatment than in the $\mathrm{W}$ treatment on day $1(8.96 \mu \mathrm{g} / \mathrm{L}$ and $35.13 \mu \mathrm{g} / \mathrm{L}$; $p<0.001$; Table 1a). This represented an $80 \%$ decrease in the chlorophyll $a$ of the $\mathrm{C}+\mathrm{W}$ treatment within $24 \mathrm{~h}$. On day 14, the $\mathrm{C}+\mathrm{W}$ treatment had a chlorophyll $a$ of $8.06 \pm 0.95 \mu \mathrm{g} / \mathrm{L}$, which was over $30 \%$ higher than all other treatments (mean $=4.87 \pm 1.41 \mu \mathrm{g} / \mathrm{L} ; p=0.19$ ). The ammonium, nitrate, and DP concentrations in the $\mathrm{C}+\mathrm{W}$ and $\mathrm{W}$ treatments were not significantly different at the end of the study period, though nitrate increased in both treatments to $1 \mathrm{mg} / \mathrm{L}$ on day 14 (Fig. 1). Total phytoplankton biomass was lower on day 14 than day 0 in both the $\mathrm{C}+\mathrm{W}$ and $\mathrm{W}$ treatments, but the difference between the initial and final biomass was larger in the $\mathrm{C}+\mathrm{W}$ treatment (Fig. 2; Table 2).

In the $\mathrm{C}+\mathrm{W}$ treatment, the biomass of all taxonomic groups decreased, especially that of Tetraedron (Kützing 1985), which disappeared by day 7 (Fig. 2). On day 7, the biomass was dominated by the "other" group, which included Peridinium (Ehrenburg 1830), Pandorina (Bory 1824), Staurastrum (Meyen ex Ralfs 1848), Crucigenia (Morren 1830), Merismopedia (Meyen 1839), Treubaria (Bernard 1908), Scenedesmus (Meyen 1829), Pediastrum (Meyen 1829), centric diatoms, desmids, and one unidentified genera. However, the biomass mostly consisted of green algae, including Pediastrum. In the $\mathrm{W}$ treatment, Tetraedron persisted and there was a shift in the dominance of the biomass from Navicula (Bory 1822) at the beginning of the experiment (35\% of total biomass) to Synedra (Ehrenberg 1830) at the end (76\% of total biomass, Fig. 2b). Although the Synedra biomass appears to be larger in the W treatment than the C $+\mathrm{W}$ treatment on day 14, this difference is not significant (two-tailed $t$ test $p=0.12$ ). On day 14, the phytoplankton biomass of the $\mathrm{W}+\mathrm{S}$ treatment was dominated by the "other" group (100\%), while the $\mathrm{C}+\mathrm{W}+\mathrm{S}$ treatment was made up of Navicula, Synedra, and "other". 


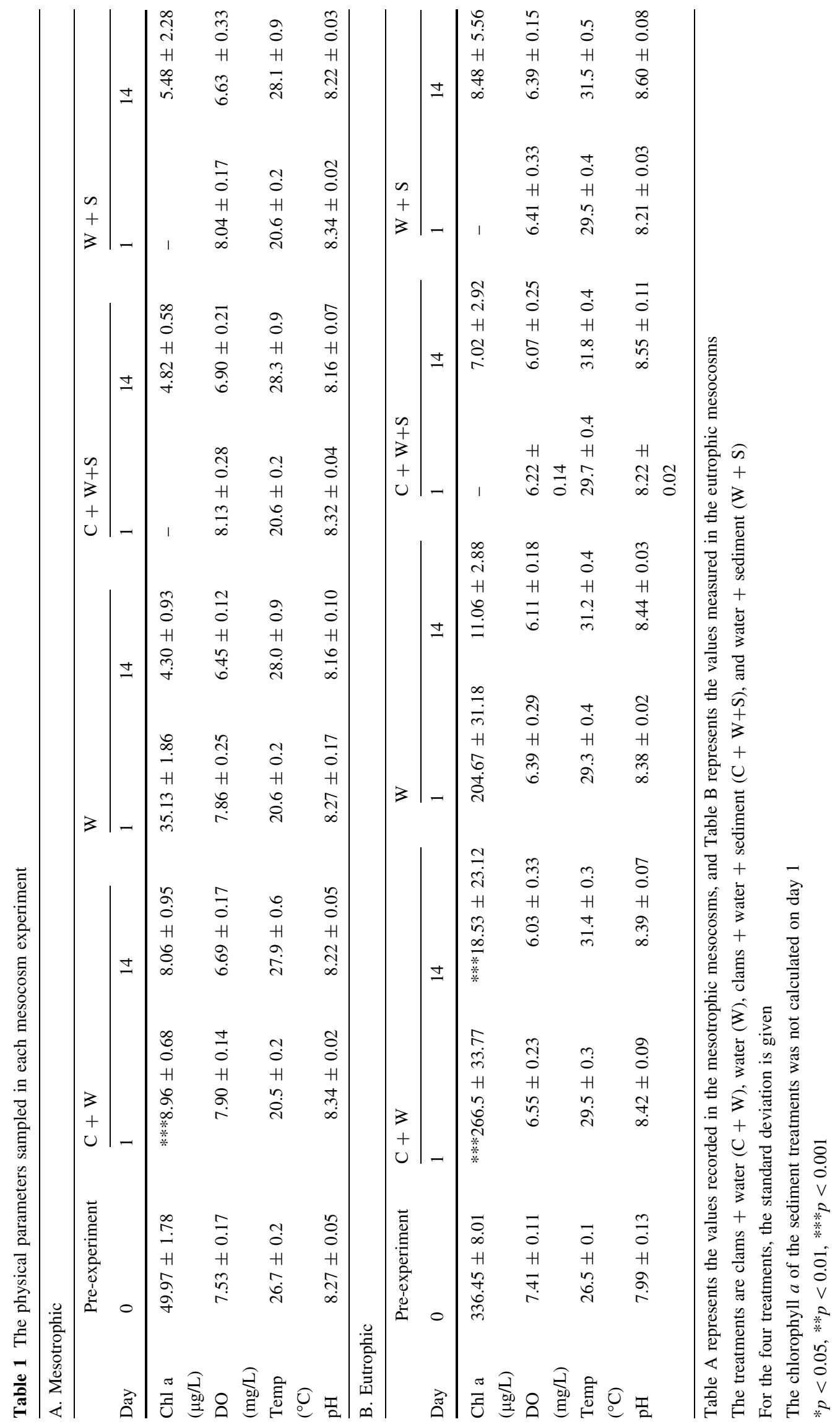



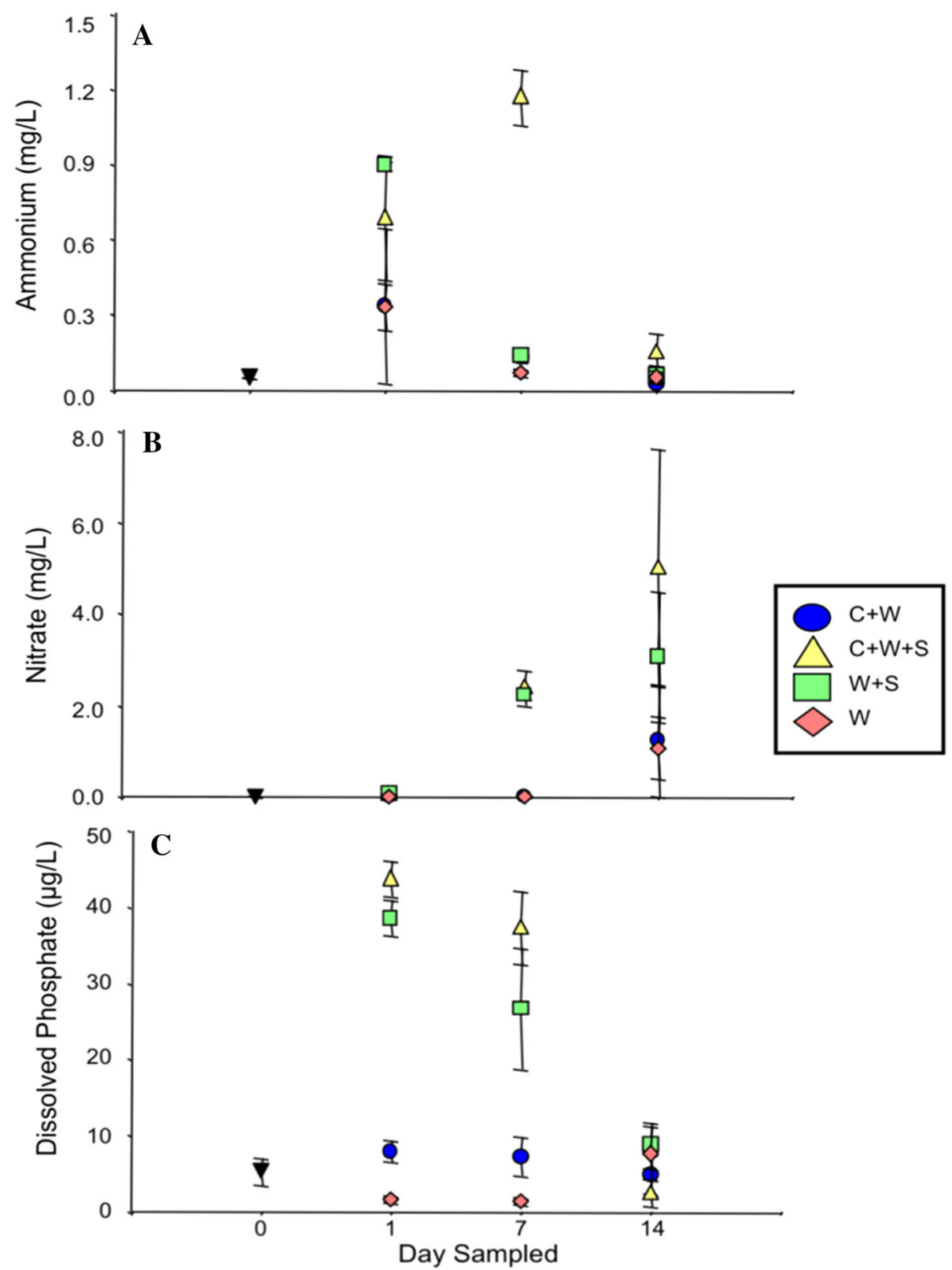

Fig. 1 Mean concentrations measured in the mesotrophic experiment for a ammonium, $\mathbf{b}$ nitrate, and $\mathbf{c}$ dissolved phosphate. Day 0 is the concentration measured in the containers, before the water was distributed. The bars associated with each point represent the standard error. If no bars are visible, it indicates a small error. Note that the scales and units are not the same

Treatments with sediment $(\mathrm{C}+\mathrm{W}+\mathrm{S}$ and $\mathrm{W}+\mathrm{S})$ had a lower phytoplankton biomass than those without sediment $(\mathrm{C}+\mathrm{W}$ and $\mathrm{W})$ on day $14(p=0.05$; Table 2$)$. In the $\mathrm{C}+\mathrm{W}+\mathrm{S}$ and $\mathrm{W}+\mathrm{S}$ treatments, ammonium concentration doubled within $24 \mathrm{~h}$ (Fig. 1a). On day 7, the $\mathrm{C}+\mathrm{W}+\mathrm{S}$ had a significantly higher ammonium concentration than $\mathrm{W}+\mathrm{S}(p=0.001)$, but this difference did not persist to day 14 (Fig. 1a). The nitrate concentration increased in both the $\mathrm{C}+\mathrm{W}+\mathrm{S}$ and $\mathrm{W}+\mathrm{S}$ treatments over the course of the experiment (Fig. 1b), but the nitrate levels between treatments were not significantly different on any day. In the $\mathrm{C}+\mathrm{W}+\mathrm{S}$ treatment, DP levels peaked on day 1 at $45 \mu \mathrm{g} / \mathrm{L}$ and then decreased by over $60 \%$ by day 14 , where the DP levels were not different between any treatments ( $p=0.49$, Fig. $1 \mathrm{c})$. 


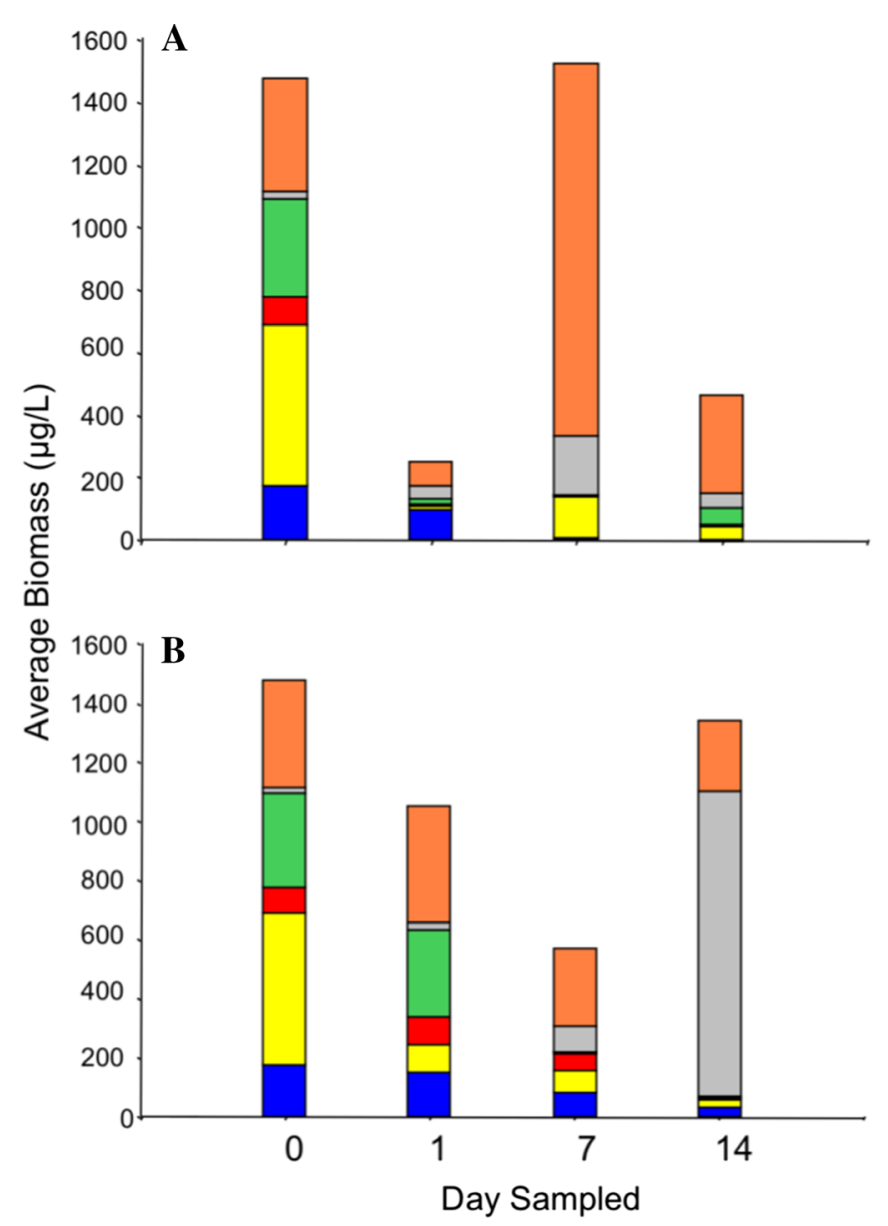

\begin{tabular}{|l|}
\hline$\square$ Tetraedron \\
$\square$ Navicula \\
$\square$ Spirulina \\
$\square$ Filamentous algae \\
$\square$ Synedra \\
$\square$ Other \\
\hline
\end{tabular}
Fig. 2 Mean biomass from the mesotrophic experiment separated by phylogenetic level for a the C $+\mathrm{W}$ treatment and $\mathbf{b}$ the $\mathrm{W}$
treatment. The levels which composed a lower percentage of the biomass were added together to form the category "other". These minor genera include Peridinium, Pandorina, Starastrum, Crucigenia, Merismopedia, Treubaria, Scenedesmus, Pediastrum, centric diatoms, desmid, and an unidentified genus

Eutrophic experiment

Chlorophyll $a$ was higher in the $\mathrm{C}+\mathrm{W}$ treatment than in the $\mathrm{W}$ treatment initially $(p<0.0001$; Table $1 \mathrm{~b})$. However, chlorophyll $a$ in the $\mathrm{C}+\mathrm{W}$ treatment decreased by $70 \%$ each sample date after day $1(p<0.001)$, while the chlorophyll $a$ in the $\mathrm{W}$ treatment decreased by over $90 \%$ from day 1 to 7 . At the end of the experiment, there was no difference in chlorophyll $a$ between the four treatments. There was no significant change in the ammonium, nitrate, or TP concentration in the treatments without sediment $(\mathrm{C}+\mathrm{W}$ and $\mathrm{W})$ throughout the experiment (Fig. 3). As observed in the mesotrophic experiment, total phytoplankton biomass was lower on day 0 compared to day 14 in both the $\mathrm{C}+\mathrm{W}$ and $\mathrm{W}$ treatments (Fig. 4).

On day 1, phytoplankton biomass in the $\mathrm{C}+\mathrm{W}$ treatment was higher than in the $\mathrm{W}$ treatment $(38.01 \mathrm{mg} / \mathrm{L}$ and $28.24 \mathrm{mg} / \mathrm{L}$, respectively; $p=0.034$; Table 2), but Peridinium dominated both treatments, comprising over $95 \%$ of the total biomass. However, Peridinium biomass in $\mathrm{C}+\mathrm{W}$ and $\mathrm{W}$ treatments decreased by over 90\% from the beginning to the middle of the experiment, and Synedra appeared on day 7 (Fig. 4). Although Synedra tended to dominate at the end of the experiment in both the C $+\mathrm{W}$ (87\% of total biomass) and W treatments (92\% of total biomass), Synedra biomass in the W treatment was nearly double that of the C $+\mathrm{W}$ treatment $(8.06 \mathrm{mg} / \mathrm{L}$ and $4.51 \mathrm{mg} / \mathrm{L}$, respectively, Fig. 4). Although the "other" group did not make up a large proportion of the phytoplankton community, it consisted of Anabaena (Bory ex Bornet and Flahault 1886), Coelastrum (Nägeli 1849), Crucigenia, desmid, Eudorina (Ehrenberg 1830), filamentous algae, Merismopedia, Pandorina, Scenedesmus, Spirogyra (Link 1820), Staurastrum, and Tetraedron. 


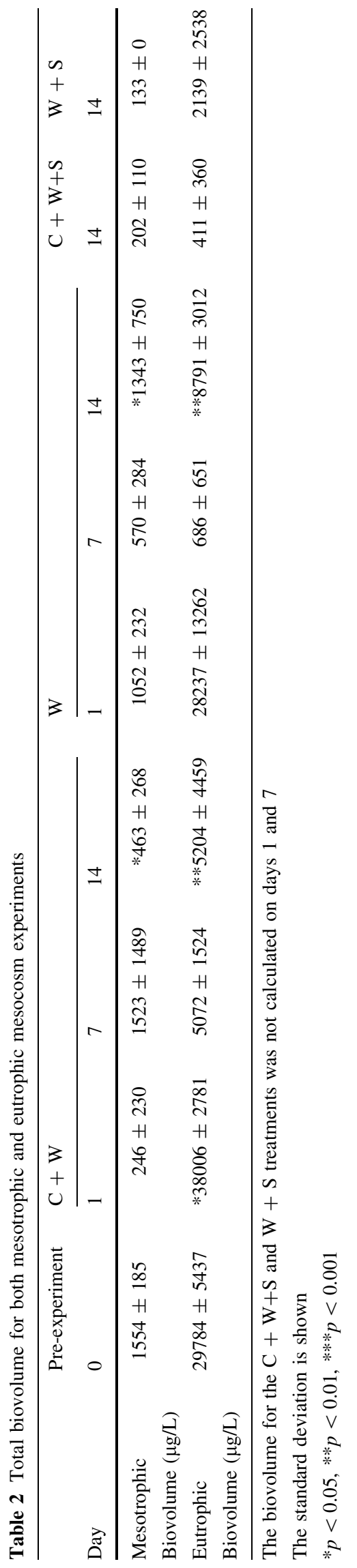



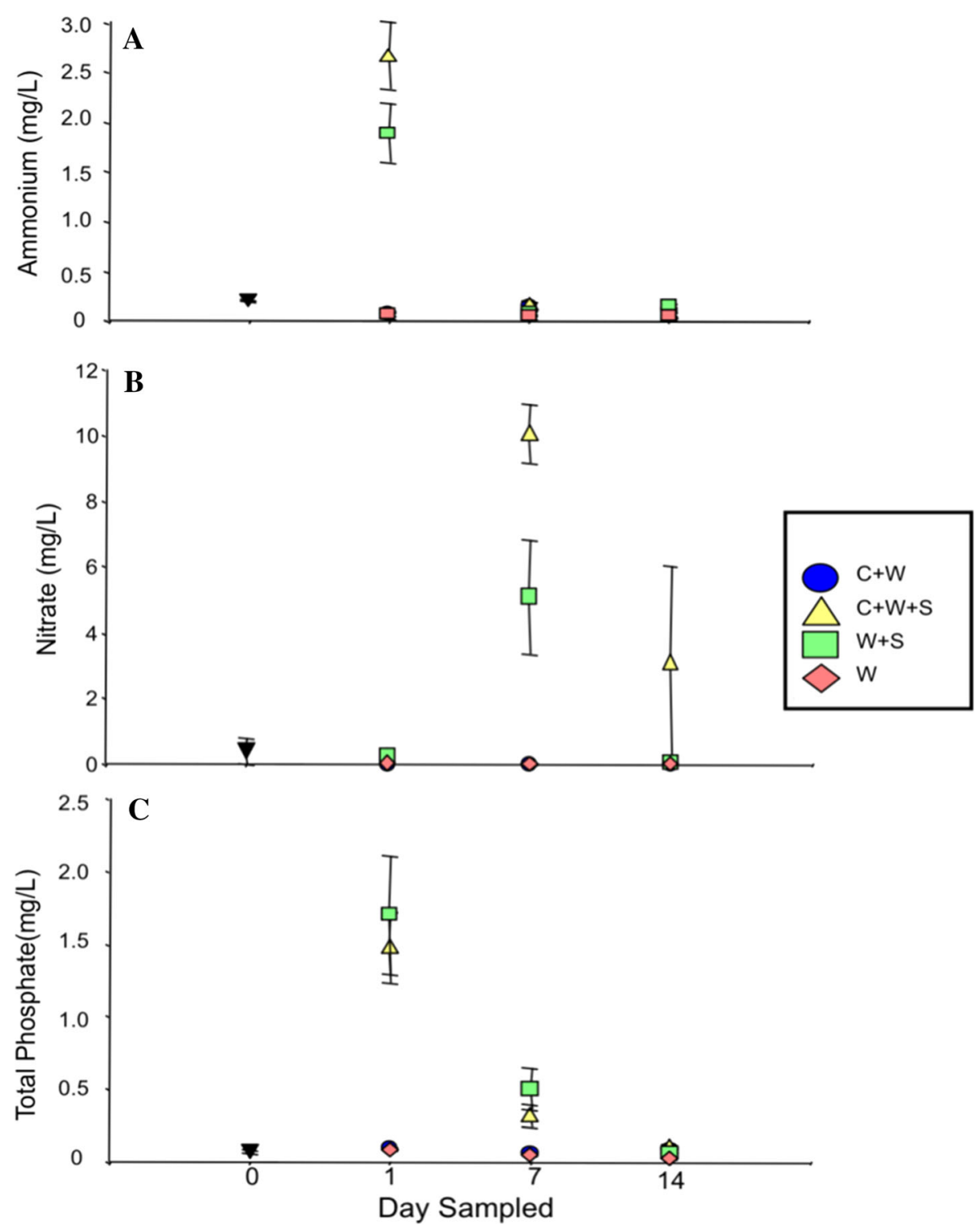

Fig. 3 Mean concentrations measured in the eutrophic experiment for $\mathbf{a}$ ammonium, $\mathbf{b}$ nitrate, and $\mathbf{c}$ total phosphate. Day 0 is the concentration measured in the containers, before the water was distributed. The bars associated with each point represent the standard error. If no bars are visible, it indicates a small error. Note the difference in scale

At the end of the experiment, treatments with sediment had lower phytoplankton biomass than those without $(p=0.021)$. On day 1 , the ammonium level was highest in the sediment treatments $(\mathrm{C}+\mathrm{W}+\mathrm{S}$ and $\mathrm{W}+\mathrm{S}$ ), with an average of $2.28 \pm 0.72 \mathrm{mg} / \mathrm{L}$ (Fig. 3a). However, on day 14, treatments with and without sediment had similar ammonium concentrations. Nitrate increased in the sediment treatments by the middle of the experiment, with the nitrate concentration of the $\mathrm{C}+\mathrm{W}+\mathrm{S}$ treatment peaking on day $7(10.06 \mathrm{mg} / \mathrm{L})$. However, there was over a 95\% decrease in the nitrate level of sediment treatments from the middle to the end of the experiment (Fig. 3b). There was an immediate increase in the TP in treatments with sediment, which then decreased over the duration of the experiment (Fig. 3c). The highest TP level was $1.59 \pm 0.63 \mathrm{mg} / \mathrm{L}$ in the sediment treatments. TP then decreased by $70 \%$ from day $1-7$, and on day 14 , there was no difference in TP between treatments $(p=0.09)$. 


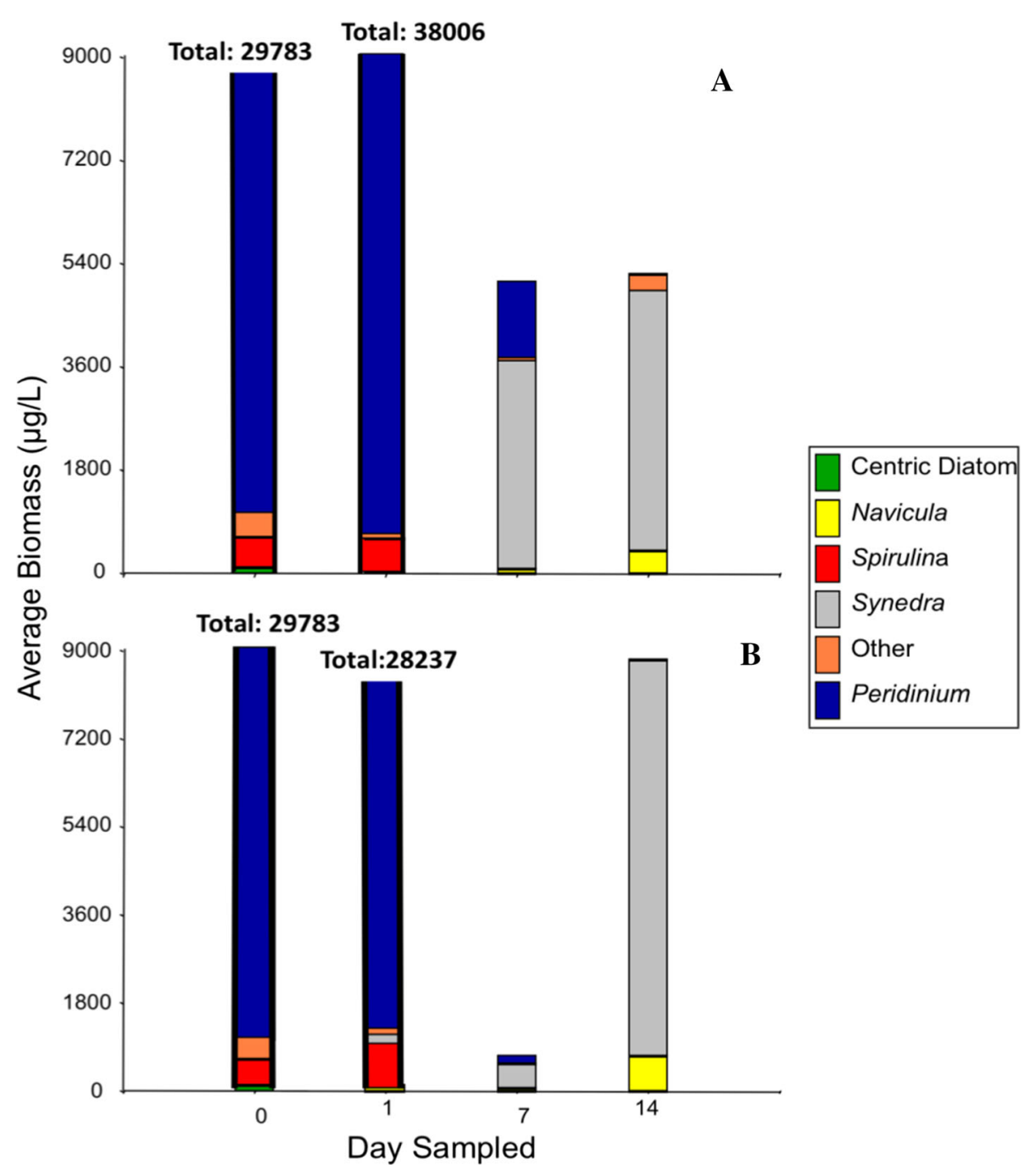

Fig. 4 The mean biomass for the eutrophic experiment separated by level for a the $\mathrm{C}+\mathrm{W}$ treatment and $\mathbf{b}$ the $\mathrm{W}$ treatment. The levels which were determined to make up a lower percentage of the biomass were added together to form the category "other". These minor genera include Starastrum, Eudorina, Scenedesmus, Merismopedia, Crucigenia, Anabaena, Pandorina, Coelastrum, Tetraedron, filamentous algae, and desmid

\section{Discussion}

Though $C$. fluminea have caused documented changes in nutrient concentration and phytoplankton communities world-wide, their impact within tropical systems are understudied (but see Linares et al. 2017). Using mesocosm experiments that represented Puerto Rican reservoirs, we examined the effect of $C$. fluminea on phytoplankton communities in systems with differing nutrient classifications. We did not observe a sustained effect on the phytoplankton community or nutrient concentration as a result of clam presence in either the mesotrophic or eutrophic mesocosm. However, there was an overall loss of phytoplankton biomass by day 14 and Synedra dominated the phytoplankton community when $C$. fluminea were excluded in treatments without sediment. The results of these mesocosm experiments suggest $C$. fluminea do not have a large effect on tropical reservoirs classified as mesotrophic or eutrophic.

Nutrient concentrations did not differ when $C$. fluminea were present in treatments without sediment, though we expected $C$. fluminea to increase nutrients through the production of metabolic wastes such as ammonium and phosphate. Although a lack of an observable effect of $C$. fluminea on nutrient concentrations is not supported by previous studies (Lauritsen and Mozley 1989; Way et al. 1990), we can explore potential driving factors. One explanation could be food limitation, as Foe and Knight (1985) found C. fluminea become 
food limited at chlorophyll $a$ concentration below $47.3 \mu \mathrm{g} / \mathrm{L}$. Although the initial chlorophyll $a$ concentration for both experiments was high $(50.0 \mu \mathrm{g} / \mathrm{L}$ in mesotrophic, $336.4 \mu \mathrm{g} / \mathrm{L}$ in eutrophic), it dropped below the suggested limiting level by the experiment's end $(5.7 \mu \mathrm{g} / \mathrm{L}$ in mesotrophic, $11.3 \mu \mathrm{g} / \mathrm{L}$ in eutrophic). Additionally, previous mesocosm studies report $C$. fluminea increase nutrients by moving nutrients from the sediment to the water column (Coelho et al. 2018) suggesting pedal feeding was occurring when these nutrients shifted. Thus, it is possible $C$. fluminea restricted to filter feeding were food limited, and this resulted in little-to-no nutrients being excreted. However, starving $C$. fluminea decrease in biomass (Vohmann et al. 2010) and we did not observe a significant change in biomass.

A compounding issue could be the water temperatures recorded during the experiments, as high temperatures elevate an ectotherm's metabolism. Given that the highest temperature measured during the study $\left(32.2^{\circ} \mathrm{C}\right)$ lies toward the upper limit of $C$. fluminea's range $\left(36^{\circ} \mathrm{C}\right.$ : McMahon 2002$), C$. fluminea would most likely have needed to consume more food than its normal metabolic rate requires (Hakenkamp and Palmer 1999). Although these temperatures may seem lethal given $C$. fluminea's historic range, we observed $C$. fluminea surviving in temperatures up to $38{ }^{\circ} \mathrm{C}$ for multiple days in pre-trial mesocosm experiments (Chappell unpublished data). Additionally, the temperatures $C$. fluminea were subjected to in the mesocosm experiments are similar to natural reservoir conditions, as temperatures of $30.9^{\circ} \mathrm{C}$ have been recorded in both the mesotrophic and eutrophic reservoirs (Chappell 2012). Dissolved oxygen concentrations may also have restricted the nutrient excretion of $C$. fluminea. Previous research found $C$. fluminea is not able to regulate its oxygen uptake as conditions become more anoxic (McMahon 2002). Despite these experiments being conducted in a seemingly high-stress environment, only one clam mortality was recorded and there was no measurable change in clam biomass from the beginning to end of both experiments. Nevertheless, the mesocosm conditions could explain why $C$. fluminea did not impact nutrient concentrations.

Although we predicted $C$. fluminea would affect the phytoplankton community, as previous research indicated that clams lower total phytoplankton biomass through filter feeding (Cohen et al. 1984; Vaughn and Hoellein 2018), this was not observed. Clams did lower the phytoplankton biomass initially in the mesotrophic experiment, but this trend was not sustained over the course of the experiment. This finding is supported by Bullard and Hershey (2013), who did not observe a large $C$. fluminea effect in their mesocosm study. The authors surmised this resulted from a combination of a short experiment time $(12 \mathrm{~h})$ and slow filter-feeding rate; however, the duration of the experiment is not likely the issue in our study. We determined ten $C$. fluminea could filter the entire $11 \mathrm{~L}$ water column within a maximum of 5 days using filtration rates found by previous studies (Way et al. 1990). Though an unusually slow filter feeding rate might be the reason there was no effect on the phytoplankton biomass by $C$. fluminea, this would not explain the decrease in phytoplankton biomass in the $\mathrm{W}$ treatments.

While $C$. fluminea did not affect the phytoplankton biomass over the long term, there were some initial changes in the phytoplankton community structure when clams were present. In the mesotrophic $\mathrm{C}+\mathrm{W}$ treatment, Tetraedron, a small green alga, was not observed in the phytoplankton community after day 7, but Pediastrum, a green alga large in size and biomass, began to increase in abundance. Loss of a phytoplankton genus was unexpected as previous studies reported no preferential feeding by C. fluminea (Way et al. 1990; Boltovskoy et al. 1995). The mechanism for the observed increase in Pediastrum could be predation escape via a reduced sinking rate due to its shape, a factor known to decrease the sinking rate of other phytoplankton genera (Padisak et al. 2003). However, it seems Pediastrum was only able to avoid C. fluminea for a short period until the individuals eventually sank and/or were consumed, as abundance declined by day 14 . Despite some initial changes, by the end of the experiment, no phytoplankton genera dominated the phytoplankton biomass when $C$. fluminea were present.

The concurrent decline in phytoplankton biomass in the $\mathrm{C}+\mathrm{W}$ and $\mathrm{W}$ treatments in both mesocosm experiments could have resulted from excess light exposure. Some phytoplankton species are sensitive to light, such as Peridinium, an armored dinoflagellate. Even though the experiment was conducted in a shaded enclosure, irradiance measurements taken above the mesocosms revealed all values were higher than the irradiance level at which significant photoinhibition has been observed for Peridinium cinctum (1100 $\left.\mu \mathrm{mol} \mathrm{m}{ }^{2} / \mathrm{s}^{1}\right)$ (Kok 1956; Regel et al. 2004). Peridinium typically migrates over $2 \mathrm{~m}$ to reach depths that are optimal for photosynthesis (Regel et al. 2004), which was not possible in the shallow mesocosms where the average depth was less than $0.5 \mathrm{~m}$. Additionally, dinoflagellates have been shown to experience negative growth rates when above an optimal depth of approximately 0.6-0.73 m (Whittington et al. 2000; Regel et al. 
2004). It is thus highly plausible Peridinium, and other phytoplankton individuals within the mesocosms, experienced photoinhibition and other stressors, such as nutrient limitation, that prevented an increase in phytoplankton biomass independent of clam presence.

One similarity between the mesotrophic and eutrophic mesocosm experiments is that the genus Synedra dominated the phytoplankton biomass by day 14 in the W treatment. Synedra is a long, needle-like pennate diatom, giving it a high surface area-to-volume ratio and thus a high affinity for phosphorus (Makulla and Sommer 1993; Grover et al. 1989). The increase in the Synedra population could be due to the genus outcompeting other phytoplankton for nutrients within the mesocosm experimental design; however, we did not see this response when clams were present $(\mathrm{C}+\mathrm{W}$ treatments). Thus, it is likely $C$. fluminea maintained a lower Synedra biomass through predation, as clams are known to consume Synedra (Boltovskoy et al. 1995).

It was difficult to determine whether allowing $C$. fluminea to filter and pedal feed $(\mathrm{C}+\mathrm{W}+\mathrm{S})$ had a different effect on the phytoplankton community or nutrient concentration as there was a high amount of suspended sediment. This initial sediment suspension within mesocosms was not a result of clam activity, but instead due to experimental design and fine sediment. Additionally, the mesocosms with sediment were not stirred to avoid sediment resuspension and to allow for chlorophyll $a$ and phytoplankton community sampling. This suggests that though we observed differences in the phytoplankton community structure between the $\mathrm{C}+\mathrm{W}+\mathrm{S}$ and $\mathrm{C}+\mathrm{W}$ treatments on day 14 , the structure could be a result of phytoplankton sinking out of the water column or a lack of light availability from the initial turbidity. Thus, conclusions related to how filter and pedal feeding interact to influence nutrients and phytoplankton in the water column remain unresolved.

Focusing on nutrient dynamics in sediment treatments, we can explore these results in the context of a sediment resuspension event, which is common in lakes (Wetzel 2001) and Puerto Rican reservoirs after large rainfall events (Yuan et al. 2015). Ammonium present in sediment can be released into the water column (Reddy et al. 1996), and previous research has found a correlation with increased water column phosphorus concentrations and the resuspension of sediment through wind action (Kristensen et al. 1992; Reddy et al. 1996). Suspended sediment in the water column is likely the source of the observed increase in phosphorus and ammonium concentrations in sediment treatments, as water transparency was inversely correlated with these levels over time (personal observation). Additionally, the spike in nitrate observed likely resulted from nitrification (Wetzel 2001). Though nitrification also occurred in treatments without sediment, sediment contains more active bacteria than the water column (Jones 1979) suggesting sediment presence will lead to increased nitrification in aerobic conditions.

We expected $C$. fluminea to have a larger effect on phytoplankton biomass in the mesotrophic system, given previous evidence suggesting the impact of invasive bivalves varies with nutrient classification (Vaughn and Hoellein 2018). Although bivalve nutrients can become less significant when nutrient levels increase in an ecosystem (Spooner et al. 2013), previous studies show C. fluminea can provide over $30 \%$ of the nutrients phytoplankton uptake (Lauritsen and Mozley 1989). However, our experimental results do not indicate an ecological effect of $C$. fluminea in either the mesotrophic or eutrophic mesocosm. This discrepancy could be an artifact of the original phytoplankton community structure. Previous studies that found the effect of invasive bivalves vary with initial nutrient concentrations focused on changes in cyanobacteria biomass, specifically Microcystis aeruginosa (Raikow et al. 2004; Sarnelle et al. 2005; Knoll et al. 2008). We may not have observed nutrient classification mediating $C$. fluminea effects, as our initial phytoplankton community contained minimal cyanobacteria and no $M$. aeruginosa. Future studies could further explore whether $C$. fluminea effects vary with nutrient classification when cyanobacteria are present.

We recognize there are many artifacts of our mesocosm experiment that could have resulted in a lack of an effect of $C$. fluminea, including low dissolved oxygen, high temperature, food limitation, and excessive irradiance. While these conditions may be stressful to $C$. fluminea, the mesocosm experiments replicate the natural Puerto Rican reservoir environment. Additionally, though treatments with clams demonstrated initial spikes in ammonium and nitrate concentrations, elevated nutrient levels did not persist through day 14 in either mesocosm study. This suggests clams may not cause a long-term increase in nutrient concentrations in tropical reservoirs. Sampling both the mesotrophic and eutrophic reservoirs for $C$. fluminea revealed nearly all individuals were less than $13 \mathrm{~mm}$ in length and likely under 1-year-old (Estrella-Riollano 2012). As $C$. fluminea has been present in the eutrophic reservoir since 2001, this indicates the survival rate for adult clams is low in these reservoirs, possibly due to harsh conditions. 
Previous studies have shown $C$. fluminea to be capable of creating large, persistent changes within an ecosystem; however, this was not the case for Puerto Rican reservoirs based on our mesocosm experiments. We suggest additional studies be conducted to further explore our initial findings and recommend future mesocosm experiments restock nutrients and shorten the duration of the experiment to avoid $C$. fluminea potentially becoming food limited. However, as this was the first attempt to examine the effects of $C$. fluminea in tropical reservoirs, these mesocosm experiments represent a key first step in understanding how these systems could change in response to an invasive bivalve. Though we did not observe long-term shifts in nutrient concentrations or phytoplankton biomass in the water column, Puerto Rican reservoir managers should continue to monitor $C$. fluminea as the clams may influence other dynamics we did not evaluate, such as water clarity or sediment microbial communities. While we recognize there are limitations to the conclusions which can be drawn from our study, our results suggest $C$. fluminea does not have the same effect in tropical reservoirs as in other freshwater systems.

Acknowledgements Funding for this study was provided by the United States Department of Agriculture T-STAR (124). Dr. Alan Wilson and Dr. Carlos Santos-Flores are kindly acknowledged for support with algal identification and calculating algal biovolume. Special thanks to the United States Forestry Service and the International Institute of Tropical Forestry's Soil and Water Quality Laboratory at the Rio Piedras Agricultural Experimental Station for processing all nutrient samples, to the Lajas Experimental Station technicians for allowing us to collect $C$. fluminea to use in this experiment, and the Puerto Rican Department of Natural and Environmental Resources for allowing us to access the reservoirs. Prior to publication, this paper was significantly improved from reviews by Dr. Elizabeth Hunter, Dr. Maura Dudley, Kelsey Solomon, Dr. Catherine Pringle, Theresa Hudson, Akanksha Sharma, and three anonymous reviewers.

Open Access This article is distributed under the terms of the Creative Commons Attribution 4.0 International License (http:// creativecommons.org/licenses/by/4.0/), which permits unrestricted use, distribution, and reproduction in any medium, provided you give appropriate credit to the original author(s) and the source, provide a link to the Creative Commons license, and indicate if changes were made.

\section{References}

Arar JE, Collins GB (1997) In vitro determination of chlorophyll and pheophytin a in marine and freshwater algae by fluorescence. Method 445.0. US Environmental Protection Agency, USA

Beasely CR, Tagliaro CH, Figueiredo WB (2003) The occurrence of the Asian clam Corbicula fluminea in the lower Amazon basin. Acta Amazonica 33(2):317-324

Boltovskoy D, Izaguirre I, Correa N (1995) Feeding selectivity of Corbicula fluminea (Bivalvia) on natural phytoplankton. Hydrobiologia 312:171-182

Bullard AE, Hershey AE (2013) Impact of Corbicula fluminea (Asian clam) on seston in an urban stream receiving wastewater effluent. Freshw Sci 32(3):976-990

Chappell J (2012) The influence of environmental variables and an invasive freshwater bivalve on the phytoplankton community of two tropical reservoirs. Thesis, University of Puerto Rico, Mayaguez

Coelho JP, Lillebo AI, Crespo D, Leston S, Dolbeth M (2018) Effect of the alien invasive bivalve Corbicula fluminea on the nutrient dynamics under climate change scenarios. Estuar Coast Shelf Sci 204:273-282

Cohen RRH, Dresler PV, Phillips EJP, Cory RL (1984) The effect of the Asiatic clam, Corbicula fluminea, on phytoplankton of the Potomac River Maryland. Limnol Oceanogr 29(1):170-180

Collins FS (1909) The green algae of North America. Tufts College Studies, Boston

Crespo D, Solan M, Leston S, Pardal MA, Dolbeth M (2018) Ecological consequences of invasion across the freshwater-marine transition in a warming world. Ecol Evol 8(3):1807-1817

De Stasio BT, Schrimpf MB, Beranek AE, Daniels WC (2008) Increased chlorophyll a phytoplankton abundance, and cyanobacteria occurrence following invasion of Green Bay, Lake Michigan by dreissenid mussels. Aquat Invasions $3(1): 21-27$

DRNA (2008) Plan Integral de Recursos de Agua. Departmento de Recursos Naturales y Ambientales. drna.pr.gov/oficinas/planintegral-de-recursis-de-agua-de-puerto-rico/. Accessed 15 Dec 2018

Estrella-Riollano A (2012) Ecology of the Asian clam, Corbicula fluminea (Muller), and its impacts on the benthic invertebrates in the Guajataca and La Plata reservoirs in Puerto Rico. Thesis, University of Puerto Rico, Mayaguez

Ferreira- Rodríguez N, Sousa R, Pardo I (2018) Negative effects of Corbicula fluminea over native freshwater mussels. Hydrobiologia 810:85-95

Foe C, Knight A (1985) The effect of phytoplankton and suspended sediment on the growth of Corbicula fluminea (Bivalvia). Hydrobiologia 127:105-115

Grover JP, Sterner RW, Robinson JL (1989) Algal growth in warm temperate reservoirs: nutrient dependent kinetics of individual taxa and seasonal patterns of dominance. Arch Hydrobiol 145:1-23

Hakenkamp CC, Palmer MA (1999) Introduced bivalves in freshwater ecosystems: the impact of Corbicula on organic matter dynamics in sandy streams. Oecologia 119:445-451 
Hill W, Knight A (1981) Food preference of the Asiatic clam (Corbicula fluminea) in the Sacramento San Joaquin delta. Estuaries 4(3):245

Hillebrand H, Durselen CD, Kirschtel D, Pollingher U, Zohary T (1999) Biovolume calculation for pelagic and benthic microalgae. J Phycol 35:403-424

Jones JG (1979) Microbial nitrate reduction in freshwater sediments. J Gen Microbiol 115:27-35

Karatayev AY, Burlakova LE, Kesterson T, Padilla DK (2003) Dominance of the Asiatic clam, Corbicula fluminea (Muller), in the bethic community of a reservoir. J Shellfish Res 22(2):487-493

Knoll LB, Sarnelle O, Hamilton SK, Kissman CEH, Wilson AE, Rose JB, Morgan MR (2008) Invasive zebra mussels (Dreissena polymorpha) increase cyanobacterial toxin concentrations in low-nutrient lakes. Can J Fish Aquat Sci 65:448-455

Kok B (1956) On the inhibition of photosynthesis by intense light. Biochim Biophys Acta 21:234-244

Kristensen P, Sondergaard M, Jeppesen E (1992) Resuspension in a shallow eutrophic lake. Hydrobiologica 228:101-109

Lauritsen DD, Mozley SC (1989) Nutrient excretion by the Asiatic clam Corbicula fluminea. J N Am Benthol Soc 8(2):134-139

Linares MS, Callisto M, Marques JC (2017) Invasive bivalves increase benthic communities complexity in neotropical reservoirs. Ecol Ind 75:279-285

Liu Y, Xie P, Wu XP (2009) Grazing on toxic and non-toxic Microcystis aeruginosa PCC7820 by Uno douglasiae and Corbicula fluminea. Limnology 10:1-5

Makulla A, Sommer U (1993) Relationships between resource ratios and phytoplankton species composition during spring in five north German lakes. Limnol Oceanogr 38(4):846-856

Martínez-Rodríguez GA, Santos-Flores CJ, Macchiavelli R, Sotomayor-Ramirez D, Pérez-Alegría L (2015) Nutrient levels associated with ecological thresholds of impairment: an approach to estimate numeric nutrient criteria for reservoirs of Puerto Rico. J Agric Univ PR 99(2):63-86

McMahon RF (2002) Evolutionary and physiological adaptations of aquatic invasive animals: $r$ selection versus resistance. Can $\mathbf{J}$ Fish Aquat Sci 59:1235-1244

Ortíz-Zayas J, Quiñones F, Palacios S, Vélez A, Mas H (2004) Características y condición de los embalses principales en Puerto Rico. Final Project Report to PR-DRNA. Oficina del Plan de Aguas, Puerto Rico

Padisak J, Soroczki-Pinter E, Rezner Z (2003) Sinking properties of some phytoplankton shapes and the relation of form resistance to morphological diversity of plankton- an experimental study. Hydrobiologia 500:243-257

Patrick CH, Waters MN, Golladay SW (2017) The distribution and ecological role of Corbicula fluminea (Muller, 1774) in a large and shallow reservoir. BioInvasions Rec 6(1):39-48

Paxinos R, Mitchell JG (2000) A rapid Utermohl method for estimating algal numbers. J Plankton Res 22(12):2255-2262

Pierzynski, GM (ed.) (2000) Methods of phosphorus analysis for soils, sediments, residuals, and waters. In: Southern Cooperative Series Bulletin vol 396, pp 1-102

Raikow DF, Sarnelle O, Wilson AE, Hamilton SK (2004) Dominance of the noxious cyanobacterium Microcystis aeruginosa in low-nutrient lakes is associated with exotic zebra mussels. Limnol Oceanogr 49(2):482-487

Reddy KR, Fisher MM, Ivanhoff D (1996) Resuspension and diffusive flux of nitrogen and phosphorus in a hypereutrophic lake. J Eviron Qual 25:363-371

Regel RH, Brookes JD, Ganf GG (2004) Vertical migration, entrainment and photosynthesis of the freshwater dinoflagellate Peridinium cinctum in a shallow urban lake. J Plankton Res 26(2):143-157

Riemann B, Simonsen P, Stensgaard L (1989) The carbon and chlorophyll content of phytoplankton from various nutrient regimes. J Plankton Res 11:1037-1045

Rosa I, Pereira JL, Gomes J, Saraiva PM, Gonçalves F, Costa R (2011) The Asian clam Corbicula fluminea in the European freshwater-dependent industry: a latent threat or a friendly enemy? Ecol Econ 70:1805-1813

Sarnelle O, Wilson AE, Hamilton SK, Knoll LB, Raikow DF (2005) Complex interactions between the zebra mussel, Dreissena polymorpha, and the harmful phytoplankter. Microcystis aeruginosa. Limnol Oceanogr 50(3):896-904

Silverman H, Achberger EC, Lynn JW, Dietz TH (1995) Filtration and utilization of laboratory-cultured bacteria by Dreissena polymorpha, Corbicula fluminea, and Carunculina texasensis. Biol Bull 189:308-319

Smith GM (1950) The Fresh-water algae of the United States. McGraw-Hill Book Company, New York

Sousa R, Antunes C, Guilhermino L (2008) Ecology of the invasive Asian clam Corbicula fluminea (Muller, 1774) in aquatic ecosystems: an overview. Ann Limnol 44(2):85-94

Spooner DE, Frost PC, Hillebrand H, Arts MT, Puckrin O, Xenopoulos MA (2013) Nutrient loading associated with agriculture land use dampens the importance of consumer mediated niche construction. Ecol Lett 16:1115-1125

Strayer DL, Caraco NF, Cole JJ, Findlay S, Pace ML (1999) Transformation of freshwater ecosystems by bivalves. Bioscience 49(1):19-27

Utermohl H (1958) Zur Vervoll Kommung der Quantitativen Phytoplankton-Methodik. Mitt Int Ver Theor Angew Limnol 9:1-38

USEPA (1999) Protocol for developing nutrient TMDLs. Office of Water. EPA 841-B-99-007. November 1999

Vaughn CC, Hakenkamp CC (2001) The functional role of burrowing bivalves in freshwater ecosystems. Freshw Biol 46:1431-1446

Vaughn CC, Hoellein TJ (2018) Bivalve impacts in freshwater and marine ecosystems. Annu Rev Ecol Evol Syst 49:183-208

Vohmann A, Borcherding J, Kureck A, Bij de Vaate A, Arndt H, Weitere M (2010) Strong body mass decrease of the invasive clam Corbicula fluminea during summer. Biol Invasions 12(1):53-64

Way CM, Hornbach DJ, Miller-Way CA, Payne BS, Miller AC (1990) Dynamics of filter feeding in Corbicula fluminea (Bivalvia: Corbiculidae). Can J Zool 68:115-120

Wehr JD, Sheath RG (2003) Freshwater algae of North America. Academic Press, Amsterdam

Wetzel RG (2001) Limnology: lake and river ecosystems, 3rd edn. Academic Press, San Diego

Whittington J, Sherman B, Gree D, Oliver RL (2000) Growth of Ceratium hirundinella in a sub-tropical Australian reservoir: the role of vertical migration. J Plankton Res 22:1025-1045 
Williams EH, Bunkley-Williams L, Lilyestom CG, Ortiz-Corps EAR (2001) A review of recent introductions of aquatic invertebrates in Puerto Rico and implications for the management of nonindigenous species. Carib J Sci 37(3-4):246-251

Yuan Y, Jiang Y, Taguas EV, Mbonimpa EG, Hu W (2015) Sediment loss and its cause in Puerto Rico watersheds. Soil 1:595-602

\section{Publisher's Note}

Springer Nature remains neutral with regard to jurisdictional claims in published maps and institutional affiliations. 